\title{
The academic dimension of university extension programs
}

\begin{abstract}
Viviane Elisângela Gomes ${ }^{(a)}$ Andrea Maria Duarte Vargas $(a)$ Efigênia Ferreira e Ferreira ${ }^{(b)}$
\end{abstract}

\footnotetext{
(a) Department of Oral Public Health, School of Dentistry, Universidade Federal de Minas Gerais - UFMG, Belo Horizonte, MG, Brazil.

(b) Pró-Reitora de Extensão, Universidade Federal de Minas Gerais - UFMG, Belo Horizonte, MG, Brazil.
}

$\mathbf{I}^{\prime}$ we think about university extension programs the way they exist today, we are bound to distance ourselves from how they used to be when they were officialized in Brazil, in 1931, with the object of becoming a channel to disseminate knowledge and learning for self-improvement. Their "assistencialist" (*) role in a learning context that ranged from broadening knowledge to rendering services remained strongly influential for a long time.

As of the 1968 Reform, the concept of a university extension program became linked to learning and research, to such an extent that these interrelated components became indissoluble. This condition is guaranteed and reinforced by the Brazilian Constitution of 1988. This indissolubility keeps the components closely united ${ }^{1}$ and enables achieving an ideal academic education. The learning process takes on an academic dimension that embraces scientific knowledge as well as ethical, political and social understanding, categories imprinted in Brazil's current National Curricular Guidelines.

The exercise of indissolubility is well represented in the so-called Healthy Schools Extension Project (Projeto de Extensão Escolas Saudáveis), in operation for some 30 years at the School of Dentistry, Universidade Federal de Minas Gerais - UFMG.

Treading the path from "assistencialism" to a transformational proposal, the project is currently based on the principles and strategies of the Health Promoting Schools (Escolas Promotoras de Saúde - EPS), a movement supported by the World Health Organization. ${ }^{2}$ The goals of this school program target the health and the quality of life of the communities served by these schools, the training of undergraduate and graduate students, and the production of knowledge. Its actions have been improved to incorporate new approaches, in line with public policies currently in effect. ${ }^{3}$

The Healthy Schools Extension Project is currently organized according to the following execution strategies:

- management strategy (consolidating partnerships),

- health practices and promotion strategy (teaching and interventional activities),

- communication strategy (dissemination and social networks), and

- systematization and knowledge production strategy (strengthening the extension-research interface).

Activities performed toward fulfilling these strategies generate credits for undergraduate and graduate students, contribute to a more integrat- 
ed curriculum, and have led to the creation of required subjects to compose the new teaching project of the UFMG School of Dentistry. The new subjects were conceived to be developed in diversified practice settings, like Child Learning Municipal Units (Unidades Municipais de Ensino Infantil - UMEI), schools, hospitals and longstanding institutions, among others.

Partnerships with professionals from the educational field have garnered greater support and interest from schools for the project, and have made it possible to create jointly made products. ${ }^{4}$ The association of this project to other projects and programs offered by UFMG has boosted the institution's interdisciplinary potential. The knowledge produced from project actions ${ }^{5,6}$ has spawned dissertations and theses, funded by the National Research Council (Conselho Nacional de Desenvolvimento Científico e Tecnológico - CNPq) and by the Minas

\section{References}

1. Moita FMGS, Andrade FCB. Ensino-pesquisa-extensão: um exercício de indissociabilidade na pós-graduação. Rev Bras Educ. 2009 May-Aug;14(41)269-80.

2. World Health Organization [homepage]. The World Health Organization's global school health initiative. Geneva: World Health Organization; 1998 [cited 2013 Jun 13]. Available from: http://www.who.int/school_youth_health/media/en/92. pdf.

3. Brasil. Ministério da Saúde. Secretaria de Vigilância em Saúde. Secretaria de Atenção à Saúde. Política Nacional de Promoção da Saúde [Internet]. 3rd ed. Brasília (DF): Ministério da Saúde; 2010. [cited 2013 Jun 10]. Available from: http:// bvsms.saude.gov.br/bvs/publicacoes/politica_nacional_promocao_saude_3ed.pdf.
Gerais Research Support Foundation (Fundação de Amparo à Pesquisa de Minas Gerais - FAPEMIG).

International partnerships forged as a consequence of the intellectual product derived from exchanges promoted by the Association of Universities of the Montevideo Group (Asociación de Universidades Grupo Montevideo - AUGM), and the consequent implementation of the Intervention Research Project (Projeto de Pesquisa com Intervenção), financed by the Coordination for the Improvement of Higher Education Personnel (Coordenação de Aperfeiçoamento de Pessoal de Nível Superior - CAPES), have given rise to a cooperative action with the Universidad Nacional de Córdoba (Argentina) and the Universidad de Concepción (Chile).

Viewing extension program actions as privileged settings for effective learning processes extends far beyond legal provisions; it provides a real life education in a living space.

4. Ferreira EF, Vargas AMD, Mattos FF, Amaral JHL, Vasconcelos M, Gomes VE. Promoção da saúde na escola: diálogos da saúde com a educação. 1st ed. Belo Horizonte: Ed. UFMG; 2012. $32 \mathrm{p}$.

5. Vargas AMD, Ferreira EF, Mattos FF, Vasconcelos M, Drumond MM, Lucas SD. O acesso aos serviços públicos de saúde em área limítrofe entre municípios. Saude Soc. 2011 JulSep;20(3):821-28.

6. Rossete Melo R, Rezende JS, Gomes VE, Ferreira EF, Oliveira AC. Sociodemographic, biological and behavioural risk factors associated with incidence of dental caries in schoolchildren's first permanent molars: a 3-year follow-up study. Eur J Paediatr Dent. 2013 Mar;14(1):8-12. 